\title{
Post-harvest and Extraction Conditions for the Optimum Alpha Glucosidase Inhibitory Activity of Stenochlaena palustris
}

\author{
Maria Dewi Puspitasari Tirtaningtyas Gunawan-Puteri ${ }^{*}$, Eisuke Kato ${ }^{2}$, Della Rahmawati ${ }^{1}$, \\ Stevan Teji ${ }^{1}$, Jevon Ardy Santoso ${ }^{1}$, Febbyandi Isnanda Pandiangan ${ }^{1}$, Yanetri Asi Nion ${ }^{3}$ \\ ${ }^{1}$ Department of Food Technology, Faculty of Life Sciences and Technology, Swiss German University, \\ Tangerang 15143, Indonesia \\ ${ }^{2}$ Laboratory of Food Science, Research Faculty of Agriculture, Hokkaido University, Sapporo 060-0808, Japan \\ ${ }^{3}$ Study Program of Agrotechnology, Department of Agriculture, Palangka Raya University, Palangka Raya \\ 74874, Indonesia
}

\begin{abstract}
Stenochlaena palustris has been studied for its anti-diabetic potency related to its alphaglucosidase inhibitory (AGI) activity. This study aimed to evaluate the impact of post-harvest and extraction conditions on the AGI activity of $S$. palustris and isolate the AGI bioactive principal component. AGI activity was calculated based on the inhibition of $S$. palustris samples against in vitro rat intestinal maltase and sucrase hydrolytic activities in enzymatic reactions. The selected extracts were subjected to activity-guided fractionation using liquid-liquid sequential separation, followed by silica N60 column chromatography. This study showed that post-harvest treatment significantly protected the AGI activity of $S$. palustris, while its optimum extract condition was observed with methanol and a smaller particle size $(<250 \mu \mathrm{m})$ at a sample to solvent ratio of 1:20 (w/v) for $24 \mathrm{~h}$. Further fractionation, followed by Liquid chromatography-mass spectrometry (LC-MS) and proton nuclear magnetic resonance (NMR) evaluation of the $S$. palustris extracts from optimum postharvest and extraction conditions, also resulted in the identification of kaempferol 3-0- $\beta$ glucopyranoside (astragalin) as the responsible bioactive AGI compound. This study's findings are expected to contribute to further study and utilization of $S$. palustris as an anti-diabetic agent based on its AGI activity.
\end{abstract}

Keywords: Alpha-glucosidase inhibitory activities; Diabetic; Kaempferol 3-0- $\beta$-glucopyranoside; Kelakai; Stenochlaena palustris

\section{Introduction}

Kelakai (Stenochlaena palustris; Figure 1) is an endemic fern used as food and traditional medicine by the Dayak ethnic society in central Kalimantan, Indonesia. $S$. palustris is also found and used for medicinal treatments in other countries (Ponnusamy et al., 2013; Neamsuvan et al., 2015). Extracts of this plant's mature (Chai et al., 2015) and young fronds (Leng, 2016) possess potent, high natural alpha-glucosidase inhibitory (AGI) activity associated with hyperglycemia treatment.

${ }^{*}$ Corresponding author's email: maria.gunawanputeri@sgu.ac.id, Tel.: +62-21-29779597 doi: 10.14716/ijtech.v12i3.4409 


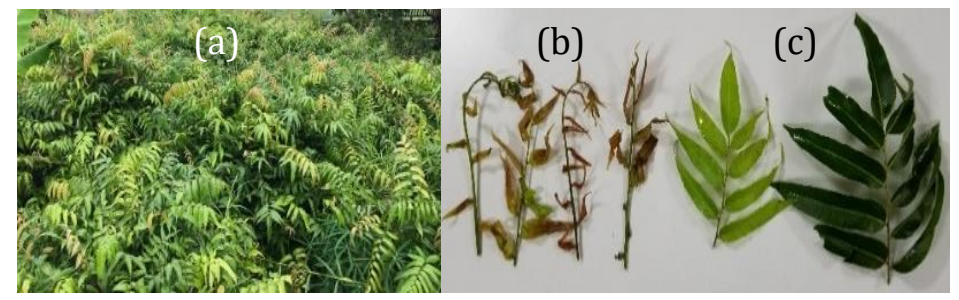

Figure 1 Left to right: (a) field; (b) young leaves; and (c) mature leaves of Stenochlaena palustris

The activities of $S$. palustris against AGI enzymes, along with its long consumption history, strongly encourage the plant's utilization as a functional food ingredient for diabetes management, especially given the rising awareness of self-monitoring and selfcontrolling blood sugar levels (Dewi et al., 2017). Common challenges in the development and production of functional food from natural products are maintaining AGI activity consistency and standardization during harvesting and processing (Widiputri et al., 2020). Extraction conditions, such as type of solvents and solvent to solid ratio, have been known to affect extraction efficiency (Dianursanti et al., 2020; Widiputri et al., 2020). To support the utilization of $S$. palustris as a functional ingredient for diabetes management, it is important to select post-harvest and extraction treatments for optimum and consistent AGI activity.

Various phenolic compound derivatives, such as flavonoids, anthocyanins, proanthocyanidins (condensed tannins), and hydroxycinnamic acids (Chai et al., 2012; Chai et al., 2015; Chear et al., 2016 Rahmawati et al., 2017), have been identified in the extracts of $S$. palustris. However, the compounds responsible for this plant species' AGI activity have not yet been confirmed. Identifying the major bioactive compounds responsible for AGI activity is also important in providing guidelines that the plant's principal activity compounds remain during harvesting and processing.

Previous studies have revealed that the water fraction of methanol extract in the mature (Chai et al., 2015) and young fronds (Leng, 2016) of S. palustris possess potent, high natural AGI activity commonly associated with hyperglycemia treatment. The first objective of this study is thus to select $S$. palustris post-harvest and extraction treatments for optimum and consistent AGI activity. Furthermore, to provide guidelines for the principal activity compounds, this study aims to identify the major bioactive compounds responsible for this plant's AGI activity using activity-guided fractionation and instrumental analysis of the isolated compounds.

\section{Methods}

\subsection{Materials}

For this study, around $15 \mathrm{~kg}$ of wild $S$. palustris plants were excavated from a $5 \times 5 \mathrm{~m}^{2}$ plot of peat land in Tumbang Nusa, Central Kalimantan, Indonesia $\left(2^{\circ} 26^{\prime} 10.5^{\prime \prime} \mathrm{S}\right.$, $114^{\circ} 10^{\prime} 24.8^{\prime \prime}$ E) during the monsoon season. The sample included young and old fronds, collected $15 \mathrm{~cm}$ from the tip of the branch. The plant materials collected were identified and deposited at the Herbarium Bogoriense, Research Center for Biology, Cibinong, Indonesia (No. 252/IPH.1.01/If.07/II/2019).

\subsection{Stenochlaena palustris Extraction}

The samples were separated into two batches of $7 \mathrm{~kg}$ each. One batch, Stenochlaena palustris 0 (SP0), was stored in an insulated container. While the other batch, Stenochlaena palustris 1 (SP1), was first grouped into 30 sprigs per group, giving 76 groups, with their cut ends covered with wet cotton, tissue, and cling wrap, tied with rubber bands, then 
wrapped with either plastic or banana leaves, and then stacked in an insulated container filled with frozen ice gel. Both SP0 and SP1 were stored in the insulated container for 2 days during transportation to the laboratory facilities to receive further treatment, including washing, oven drying at $40^{\circ} \mathrm{C}$, and chopping.

Both SP0 and SP1 were extracted at a ratio of 1:10 (m/v) using deionized water, $50 \%$ aqueous methanol ( $50 \%$ methanol), and methanol as solvents. Then, the mixtures were agitated using a twist mixer (50 rpm, $24 \mathrm{~h}$ at room temperature), centrifuged (6000 rpm for $20 \mathrm{~min}$ ), and concentrated with a rotary evaporator at $35^{\circ} \mathrm{C}$, followed by vacuum drying until they arrived at a constant weight. The water extract was then freeze-dried. All extracts were subjected to an AGI activity assay with sucrose and maltose as substrates. The solvent used in the extract with the highest AGI activity was used for further evaluation of the extraction conditions' effects on AGI activity. The evaluated extraction conditions were particle size, extraction ratio, and extraction time. Optimum extraction conditions were further applied in extracting $S$. palustris for the fractionation and evaluation of its principal AGI activity component.

\subsection{Stenochlaena palustris Fractionation}

Methanolic extract of the S. palustris went through two level fractionations, as shown in Figure 2. Activity-guided fractionation was performed via AGI activity evaluation for each vacuum-dried fraction $\left(35^{\circ} \mathrm{C}\right)$. Selected extract powder went through liquid-liquid fractionation (n-hexane, ethyl acetate, butanol, and water, ratio 1:50 (w/v)). The fraction with the highest AGI activity was further fractionated using silica N60 gel column chromatography, resulting in six fraction groups (f1-f6). The fraction with the highest AGI activity from the second fractionation was evaluated using liquid chromatography-mass spectrometry (LC-MS) at a $200 \mu \mathrm{l} / \mathrm{min}$ flow rate with gradient eluent for the first $30 \mathrm{~min}$ (start - 95:5 water:methanol, end - 5:95 water:methanol) and static eluent (5:95 water:methanol) for another $5 \mathrm{~min}$. Proton nuclear magnetic resonance ( $\left.{ }^{1} \mathrm{H} \mathrm{NMR}\right)$ was done using deuterated methanol-d4 (CD30D-d4) as a solvent at $400 \mathrm{MHz}$.

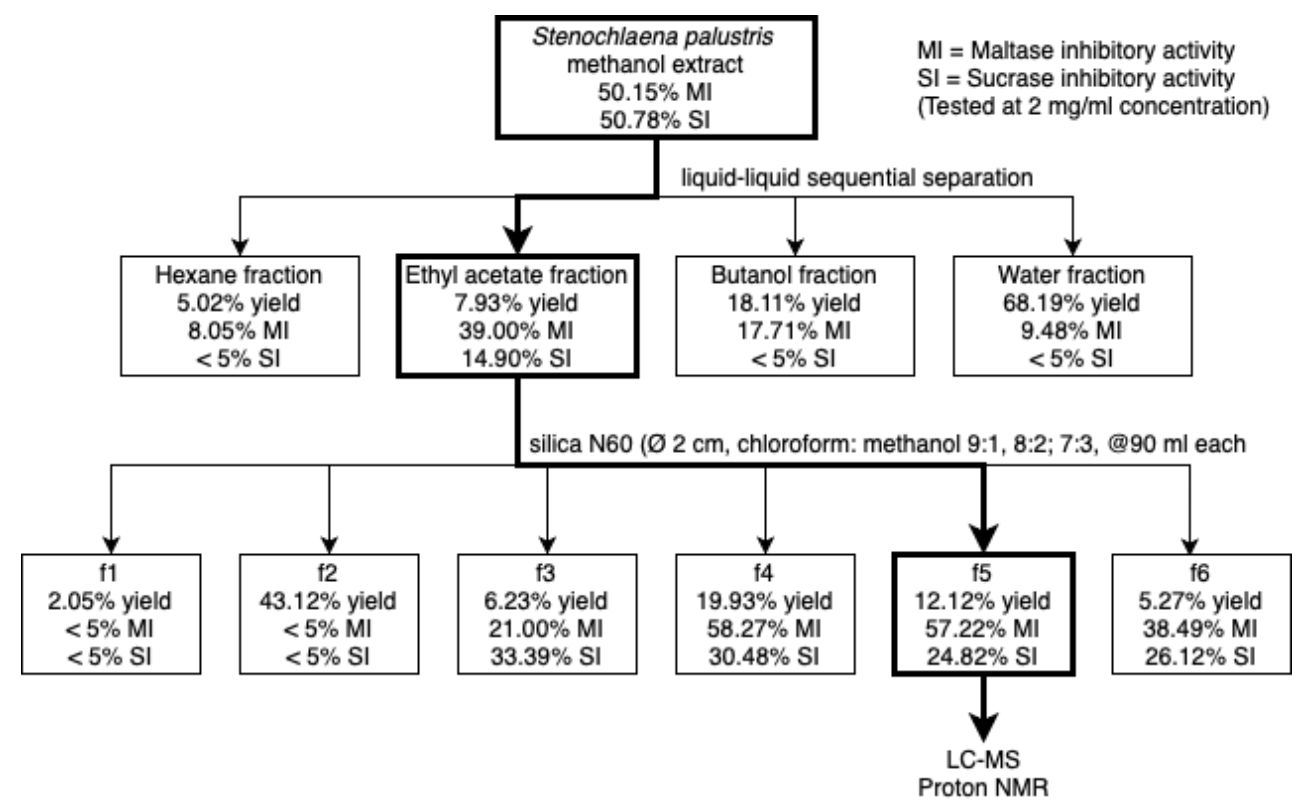

Figure 2 Fractionation scheme of the Stenochlaena palustris leaves' methanol extract

\subsection{Alpha Glucosidase Inhibitory Activity Evaluation}

The AGI activity evaluation was conducted according to Gunawan-Puteri and Kawabata (2010) with a slight modification in the centrifugation conditions. Rat intestinal glucosidase 
was extracted from commercial intestinal acetone powder. This powder measured $0.1 \mathrm{~g}$ and was mixed with $2 \mathrm{ml}$ of a $0.1 \mathrm{M}$ potassium phosphate buffer (pH 6.9). The mixture was shaken on a seesaw shaker for $5 \mathrm{~min}$, then centrifuged at 15,000 rpm. Afterward, the supernatant was recovered and stored on ice, as well as considered glucosidase possessing the AGI activity to hydrolyze maltose and sucrose.

Each sample was tested for AGI activity with two sample replications (duplo). For elution, 50\% dimethyl sulfoxide (DMSO) was used to dissolve the samples until they reached 10 times the intended testing concentration. First, $5 \mu$ of sample solution was added to a $0.2 \mathrm{ml}$ polymerase chain reaction (PCR) tube labeled either sample or sample blank, while $5 \mu$ of $50 \%$ DMSO was added to similarly sized tubes labeled either control or control blank. Then, $25 \mu \mathrm{l}$ of substrate in the $50 \%$ DMSO solution $(2.88 \mathrm{mg} / \mathrm{ml}$ of maltose for the maltase inhibition assay, $21.90 \mathrm{mg} / \mathrm{ml}$ sucrose for the sucrase inhibition assay) was added to each tube and agitated with a vortex. The pre-incubated $\left(37^{\circ} \mathrm{C}, 5 \mathrm{~min}\right)$ mixtures in the sample and control tubes were given $20 \mu \mathrm{l}$ of the rat intestinal glucosidase solution, while those in the blanks were given $20 \mu \mathrm{l}$ of potassium phosphate buffer. The mixtures were further incubated at $37^{\circ} \mathrm{C}(20 \mathrm{~min}$ for the maltase inhibition assay, $25 \mathrm{~min}$ for the sucrose inhibition assay) to allow glucosidase hydrolytic activity to take place, and $150 \mu \mathrm{l}$ of Tris- $\mathrm{HCl}$ solution ( $\mathrm{pH} 7$ ) was added to stop the reactions. All mixtures were then passed through a short Cosmosil column made from a shortened Pasteur pipette, cotton, and $1 \mathrm{mg}$ of Cosmosil 75C18-OPN gel. Samples of the filtered mixtures were taken $(20 \mu \mathrm{l}$ for the maltase inhibition assay, $30 \mu \mathrm{l}$ for the sucrose inhibition assay), mixed with $200 \mu \mathrm{l}$ of a glucose CII test-kit Wako® solution in a 96 well plate, and incubated $\left(37^{\circ} \mathrm{C}, 5 \mathrm{~min}\right)$, with absorbance measured at $505 \mathrm{~nm}$. AGI activity was evaluated based on inhibition against sugar hydrolysis and calculated using Equation 1, where A is absorbance. The experiment's results were statistically analyzed using analysis of variance, followed by a Tukey honestly significant difference (HSD) post-hoc test in OpenSTAT.

$$
\% \text { Inhibition }=\frac{\left(\left(A_{\text {control }}-A_{\text {control blank }}\right)-\left(A_{\text {sample }}-A_{\text {sample blank }}\right)\right)}{\left(A_{\text {control }}-A_{\text {control blank }}\right)} \times 100 \%
$$

\section{Results and Discussion}

\subsection{Impact of Harvesting Technique and Extraction Solvent}

AGI compounds in plants are secondary metabolites that are highly dependent on various environmental factors, such as light, temperature, soil water, soil fertility, and salinity. Accordingly, if one of these factors changes, it may alter the content of secondary metabolites as well (Yang et al., 2018). S. palustris can remain fresh up to 2 days after harvesting before it wilts. Restricted access to moisture after harvesting enhances the degenerative process of senescence. Browning in S. palustris is an example of a change that became noticeable on the fourth day after harvesting and even more obvious during the seventh day after harvesting. Aside from browning, shriveling and weight loss were also core problems in the post-harvest period (Nicholas et al., 2013). Slowing down the rate of senescence by storing the fronds at a low temperature is a common practice to delay color changes and moisture loss. In this study, one batch of the sample received additional postharvesting treatments (SP1). The cut ends of the ferns were covered with wet cotton, then wrapped with either plastic or banana leaves to preserve moisture and thereby delay drought-caused senescence.

Statistical analysis showed SP1 had significantly higher AGI activity and extract yields (Table 1). SP1 was extracted using 50\% methanol and showed more than $50 \%$ inhibitory activity against both sucrase and maltase hydrolysis. Meanwhile, only the methanolic extract of SP0 showed an inhibitory effect at a weaker level (33.72\%). The data further 
indicated that the methanol solvent had better extraction capabilities when extracting the principal AGI components from S. palustris. The extract yield from SP1 was also 4.4 to 5.6 times greater than the SP0 extract yield with the same solvents. SP0 and SP1 consistently showed methanol could better extract principal AGI components. SP1, which received additional post-harvest treatment, also featured better AGI activity in comparison to SP1 collectively. Previous studies have shown the influence of environmental factors (Quan and Liang, 2017; Yang et al., 2018), age and part of plant (Chen et al., 2018), and growing area (Chai et al., 2015; Leng, 2016) on the AGI activity of S. palustris. However, this is the first study to show the significant impact of post-harvest treatment on the plant's AGI activity.

Table 1 Impact of post-harvest treatment and extraction solvent on alpha glucosidase inhibitory (AGI) activity in Stenochlaena palustris

\begin{tabular}{llccc}
\hline \multirow{2}{*}{ Post-harvest treatment } & \multicolumn{1}{c}{$\begin{array}{c}\text { Extraction } \\
\text { solvent }\end{array}$} & \multicolumn{2}{c}{$\begin{array}{c}\text { AGI activity } \\
(10 \mathrm{mg} / \mathrm{ml})^{*}\end{array}$} & $\begin{array}{c}\text { Extraction yield } \\
(\%)^{*}\end{array}$ \\
\cline { 2 - 4 } & \multicolumn{1}{c}{ Maltase } & Sucrase & \\
\hline \multirow{2}{*}{ Standard collection } & Distilled water & $<5 \%$ & $<5 \%$ & $1.35 \pm 0.67^{\mathrm{a}}$ \\
(SP0) & $50 \%$ methanol & $<5 \%$ & $<5 \%$ & $6.23 \pm 3.11^{\mathrm{b}}$ \\
\cline { 2 - 4 } Collection with post- & Methanol & $33.72 \pm 2.51^{\mathrm{a}}$ & $<5 \%$ & $2.06 \pm 0.53^{\mathrm{a}}$ \\
harvest treatment & Distilled water & $24.76 \pm 3.59^{\mathrm{a}}$ & $28.13 \pm 1.13^{\mathrm{a}}$ & $6.00 \pm 1.24^{\mathrm{b}}$ \\
(SP1) & 50\% methanol & $54.84 \pm 1.50^{\mathrm{b}}$ & $51.07 \pm 9.60^{\mathrm{b}}$ & $28.05 \pm 0.91^{\mathrm{d}}$ \\
\hline
\end{tabular}

${ }^{*}$ Results are shown as mean \pm standard deviation. Different letters in the same column represent a statistical difference at $\mathrm{p}<0.05$

The solubility of all compounds was affected by both their own nature and their solvents (Chebil et al., 2007). Water and methanol have different polarities and affinities, so they will extract different types and/or amounts of compounds. As such, the water extract of $S$. palustris had a clear brown color, its methanolic extract a deep green colorwhich might be caused by the chlorophyll known to easily dissolve in methanol-and the $50 \%$ aqueous methanol extract a cloudy brownish green color (Figure 3 ).

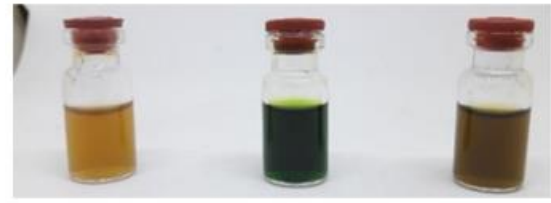

(a)

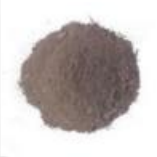

(b)

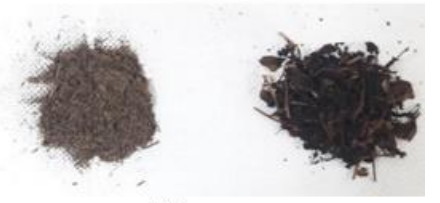

Figure 3 Left to right: (a) water, methanolic, and 50\% aqueous methanolic extracts of Stenochlaena palustris leaves; (b) Fine powder, coarse powder, and un-milled samples of Stenochlaena palustris leaves

SP1's methanolic and 50\% methanolic extracts exhibited higher AGI activity than its water extract (Table 1). Methanol has the ability to extract more secondary metabolites from plants, which were the target compounds in this analysis (Abarca-Vargas et al., 2016; Namvar et al., 2017). Previous research conducted on S. palustris also indicated that alkaloid and phenolic groups were possible compounds responsible for the plant's AGI activity (Chai et al., 2015; Leng, 2016). The 50\% methanolic extract had more yield and similar activity to the methanolic extract. However, the water content in the solvent reduces evaporation efficiency and increases the possible contamination of inactive materials dissolved in water. Therefore, methanol was selected as a solvent for further stages of this study. 


\subsection{Impact of Extraction Conditions}

The impact of the extraction conditions (particle size, extraction ratio, and extraction time) on AGI activity was observed in SP0's methanolic extract (Table 2). Particle size has been shown to affect the extracted solid yield from S. palustris (Wijaya et al., 2017) and the AGI activity of other plants (Çam and İçyer, 2013). Extraction ratio and time have also been studied for their impact on the AGI activity of other plants (Gunawan-Puteri et al., 2016). In this study, particle size significantly affected both the activity and yield of the extracts $(\mathrm{p}<0.05)$. Extraction ratio only affected yield, while extraction time did not have a significant impact $(\mathrm{p}<0.05$; Table 2).

Table 2 Impact of dominant particle size, sample to solvent ratio, and extraction time on the alpha glucosidase inhibitory (AGI) activity of Stenochlaena palustris

\begin{tabular}{|c|c|c|c|c|}
\hline Dominant particle size $(\mu \mathrm{m})$ & $\begin{array}{c}\text { Sample to } \\
\text { solvent ratio } \\
(\mathrm{w} / \mathrm{v})\end{array}$ & $\begin{array}{l}\text { Extraction } \\
\text { time }(\mathrm{h})\end{array}$ & $\begin{array}{c}\text { Maltase inhibitory } \\
\text { activity } 10 \mathrm{mg} / \mathrm{ml} \\
(\%)\end{array}$ & $\begin{array}{c}\text { Extract yield } \\
(\%)\end{array}$ \\
\hline \multirow[t]{9}{*}{$>5600$ (un-milled) } & $1: 10$ & 24 & $33.11 \pm 2.06$ & $1.35 \pm 0.08$ \\
\hline & & 48 & $31.67 \pm 1.60$ & $1.68 \pm 0.03$ \\
\hline & & 72 & $28.59 \pm 2.01$ & $1.56 \pm 0.12$ \\
\hline & $1: 20$ & 24 & $31.17 \pm 2.02$ & $1.98 \pm 0.09$ \\
\hline & & 48 & $27.62 \pm 1.52$ & $2.19 \pm 0.15$ \\
\hline & & 72 & $27.47 \pm 1.49$ & $2.04 \pm 0.12$ \\
\hline & $1: 30$ & 24 & $26.11 \pm 1.47$ & $2.62 \pm 0.07$ \\
\hline & & 48 & $35.58 \pm 3.62$ & $3.04 \pm 0.53$ \\
\hline & & 72 & $36.02 \pm 2.43$ & $2.12 \pm 0.06$ \\
\hline \multirow[t]{9}{*}{ 630-2000 (coarse powder) } & $1: 10$ & 24 & $33.15 \pm 1.18$ & $2.36 \pm 0.22$ \\
\hline & & 48 & $34.21 \pm 0.97$ & $2.79 \pm 0.28$ \\
\hline & & 72 & $39.05 \pm 2.11$ & $2.48 \pm 0.49$ \\
\hline & $1: 20$ & 24 & $38.31 \pm 1.92$ & $2.68 \pm 0.18$ \\
\hline & & 48 & $33.15 \pm 1.90$ & $3.50 \pm 0.16$ \\
\hline & & 72 & $31.11 \pm 1.45$ & $4.12 \pm 1.33$ \\
\hline & $1: 30$ & 24 & $28.17 \pm 1.62$ & $3.68 \pm 0.20$ \\
\hline & & 48 & $30.34 \pm 1.46$ & $4.04 \pm 0.69$ \\
\hline & & 72 & $32.57 \pm 1.16$ & $4.82 \pm 2.66$ \\
\hline \multirow[t]{9}{*}{$<250$ (fine powder) } & $1: 10$ & 24 & $36.18 \pm 2.56$ & $2.64 \pm 0.34$ \\
\hline & & 48 & $33.24 \pm 0.99$ & $3.09 \pm 0.15$ \\
\hline & & 72 & $29.91 \pm 1.36$ & $2.58 \pm 0.44$ \\
\hline & $1: 20$ & 24 & $30.75 \pm 2.79$ & $3.28 \pm 0.06$ \\
\hline & & 48 & $31.86 \pm 2.41$ & $4.31 \pm 0.76$ \\
\hline & & 72 & $40.69 \pm 1.51$ & $4.05 \pm 1.38$ \\
\hline & $1: 30$ & 24 & $37.72 \pm 1.61$ & $4.51 \pm 0.30$ \\
\hline & & 48 & $37.89 \pm 1.42$ & $4.30 \pm 0.61$ \\
\hline & & 72 & $39.47 \pm 0.78$ & $3.79 \pm 0.65$ \\
\hline \multicolumn{5}{|c|}{ Marginal mean extract AGI activity and yield from various particle sizes } \\
\hline$>5600$ (un-milled) & & & $30.82 \pm 2.02^{\mathrm{a}}$ & $2.06 \pm 0.14^{a}$ \\
\hline $630-2000$ (coarse powder) & & & $33.34 \pm 1.53^{\mathrm{b}}$ & $3.39 \pm 0.69 \mathrm{~b}$ \\
\hline$<250$ (fine powder) & & & $35.30 \pm 1.71^{\mathrm{c}}$ & $3.62 \pm 0.52^{b}$ \\
\hline \multicolumn{5}{|c|}{ Marginal mean extract AGI activity and yield from various extraction ratios } \\
\hline & $1: 10$ & & $33.23 \pm 1.65^{\mathrm{a}}$ & $2.28 \pm 0.24^{\mathrm{a}}$ \\
\hline & $1: 20$ & & $32.46 \pm 1.89^{\mathrm{a}}$ & $3.13 \pm 0.47^{b}$ \\
\hline & $1: 30$ & & $33.76 \pm 1.73^{\mathrm{a}}$ & $3.66 \pm 0.64^{b}$ \\
\hline \multicolumn{5}{|c|}{ Marginal mean extract AGI activity and yield from various extraction times } \\
\hline & & 24 & $32.74 \pm 1.91^{\mathrm{a}}$ & $2.79 \pm 0.17^{a}$ \\
\hline & & 48 & $32.84 \pm 1.77^{a}$ & $3.22 \pm 0.37 \mathrm{a}$ \\
\hline & & 72 & $33.88 \pm 1.59 \mathrm{a}$ & $3.06 \pm 0.81^{\mathrm{a}}$ \\
\hline
\end{tabular}

${ }^{*}$ Different letters in the same column from the same extraction condition represent statistical differences at 
$\mathrm{p}<0.05$

Further statistical analysis of samples with three particle sizes (Figure 3b) via a Tukey HSD post-hoc test showed that lowering particle size significantly increased extract AGI activity. Milling the samples into powder, whether coarse or fine, also significantly increased extract yield compared to un-milled samples. Extraction ratio did not show any significant impact on AGI activity in the $S$. palustris extracts. However, a Tukey HSD posthoc test showed that the extract yield with a 1:20 extraction ratio $(\mathrm{w} / \mathrm{v})$ was significantly higher compared to that with a 1:10 ratio, but not significantly different from the yield with a 1:30 ratio. Therefore, for the following stage of principal component isolation, methanolic extraction was applied to SP1's fine S. palustris powder at the extraction ratio (w/v) 1:20. Since the extraction period did not show any influence on AGI activity or $S$. palustris extract yield, the shortest extraction period (24 h) was selected for efficiency.

\subsection{Principal Component Isolation}

Principal component isolation was conducted and produced four fractions. The four fractions were significantly different in yield and maltase hydrolytic activity (Table 3).

Table 3 Alpha glucosidase inhibitory (AGI) activity and yield of the four fractions resulting from principal component isolation

\begin{tabular}{lccc}
\hline \multicolumn{1}{c}{ Sample $(2 \mathrm{mg} / \mathrm{mL})$} & Maltase inhibition (\%) & Sucrase inhibition (\%) $^{*}$ & Yield (\%) \\
\hline Ethyl acetate fraction & $39.00 \pm 0.11^{\mathrm{b}}$ & $14.90 \pm 6.09^{\mathrm{c}}$ & 7.93 \\
Butanol fraction & $17.71 \pm 4.37^{\mathrm{a}}$ & $3.99 \pm 5.64^{\mathrm{c}}$ & 18.11 \\
Water fraction & $9.48 \pm 3.18^{\mathrm{a}}$ & $1.88 \pm 2.65^{\mathrm{c}}$ & 68.19 \\
Hexane fraction & $8.05 \pm 6.16^{\mathrm{a}}$ & $0.91 \pm 1.28^{\mathrm{c}}$ & 5.02 \\
\hline
\end{tabular}

${ }^{*}$ Results are shown as mean \pm standard deviation. Different letters in the same column represent statistical differences at $\mathrm{p}<0.05$

A Tukey HSD post-hoc test indicated that the ethyl acetate fraction had significantly higher maltase inhibitory activity compared to the other fractions and that all four fractions had significantly different yields: the highest was the water fraction, followed by the butanol, ethyl acetate, and hexane fractions. Ethyl acetate is known to dissolve alkaloids, polyphenols, tannins, flavonoids, terpenes, steroids, and quinones (Gangula et al., 2013; Mustarichie et al., 2017). The ethyl acetate S. palustris extract also contained high amounts of alkaloids, flavonoids, phenols, and saponins, moderate amounts of terpenoids, and a low number of glycosides and tannins (Arullappan et al., 2017; Saragih et al., 2017).

The ethyl acetate fraction was subjected to a second stage of fractionation using silica $60 \mathrm{~N}$ column chromatography and three different eluents (chloroform:methanol (v/v) = 9:1, $8: 2$, and 7:3). Normal phase silica plate thin layer chromatography (TLC) was used to evaluate the extracted compounds, and those with separation profile similarity were grouped into similar fractions, resulting in six fractions named f1-f6 (Figure 4), whose AGI activity is shown in Table 4.

Table 4 Alpha glucosidase inhibitory (AGI) activity and yield of the four fractions resulting from principal component isolation

\begin{tabular}{ccc}
\hline Sample $(2 \mathrm{mg} / \mathrm{ml})$ & Maltase inhibition $(\%)^{*}$ & Sucrase inhibition $(\%)^{*}$ \\
\hline Ethyl acetate fraction & $38.20 \pm 1.76^{\mathrm{a}}$ & $21.35 \pm 3.49^{\mathrm{a}}$ \\
f1 & $0.07 \pm 0.10^{\mathrm{b}}$ & $0.35 \pm 0.49^{\mathrm{b}}$ \\
f2 & No inhibition & No inhibition \\
f3 & $21.00 \pm 3.56^{\mathrm{c}}$ & $33.39 \pm 1.73^{\mathrm{c}}$ \\
f4 & $58.27 \pm 0.13^{\mathrm{d}}$ & $30.48 \pm 3.38^{\mathrm{a}, \mathrm{c}}$ \\
f5 & $57.22 \pm 1.63^{\mathrm{d}}$ & $24.82 \pm 1.14^{\mathrm{a}, \mathrm{c}}$
\end{tabular}


f6

$38.49 \pm 0.93^{\mathrm{a}}$

$26.12 \pm 2.30^{\mathrm{a}, \mathrm{c}}$

${ }^{*}$ Results are shown as mean \pm standard deviation. Different letters in the same column represent statistical differences at $\mathrm{p}<0.05$

Fractions $\mathrm{f} 1$ and $\mathrm{f} 2$ showed no AGI activity and were thus excluded from the statistical evaluation of inhibitory activity against maltase and sucrase. Fractions f3-f6 were significantly different in their activity against maltase but not against sucrase. A Tukey HSD post-hoc test indicated that fractions $\mathrm{f} 4$ and f5 were significantly higher in maltase inhibitory activity compared to fractions $\mathrm{f} 3$ and $\mathrm{f} 6$. Though $\mathrm{f} 5$ had a significantly lower yield compared to f4, the TLC evaluation showed that f5 had better purity (Figure 4), so it was selected for the next purification and identification stage.

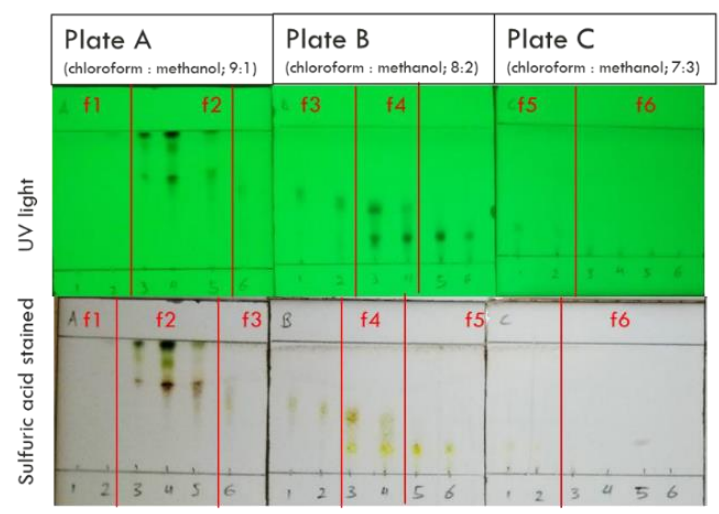

Figure 4 TLC profile of the fractions resulting from silica N60 column chromatography of the ethyl acetate fraction from the methanolic extract of Stenochlaena palustris leaves

Fraction f5 was subjected to liquid chromatography-mass spectroscopy (LC-MS), which revealed an active compound detected between minutes 16.85 and 17.06 (Figure 5c) that was also observed as a major peak in the original ethyl acetate fraction (Figure 5b) and even in the $S$. palustris leaves' original methanolic extract (Figure 5a). The mass spectrum evaluation showed matching $\mathrm{m} / \mathrm{z}$ with kaempferol 3-0- $\beta$-glucopyranoside or astragalin (Figure 5d) with electrospray ionization-mass spectroscopy ESI-MS (negative): $\mathrm{m} / \mathrm{z} 447$ [M-H]-, 493 [M+FA-H]-, 895 [2M-H]-; and (positive): m/z 449 [M+H]+, 471 [M+Na]+, 897 $[2 \mathrm{M}+\mathrm{H}]+, 919[2 \mathrm{M}+\mathrm{Na}]+$. Further, a ${ }^{1} \mathrm{H}$ NMR evaluation with CD30D-d4 as a solvent from the isolated peak of fraction f5 showed a corresponding signal to astragalin ${ }^{1} \mathrm{H}$ NMR (500 $\mathrm{MHz}, \mathrm{CDCl} 3, \mathrm{rt})$ : 8.05-8.03 (2H), 6.88-6.86 (2H), 6.38-6.31 (2H), 6.19 (2H), 5.25-5.23 (2H). Therefore, astragalin was confirmed as the principal AGI activity component in the $S$. palustris methanolic extract. Astragalin was previously found in S. palustris, along with other phytochemicals (Tan et al., 2013; Nurmilatina, 2017). Other studies have similarly shown that astragalin has high AGI activity (Choung et al., 2017), though none of these were conducted with $S$. palustris extracts.

(a)

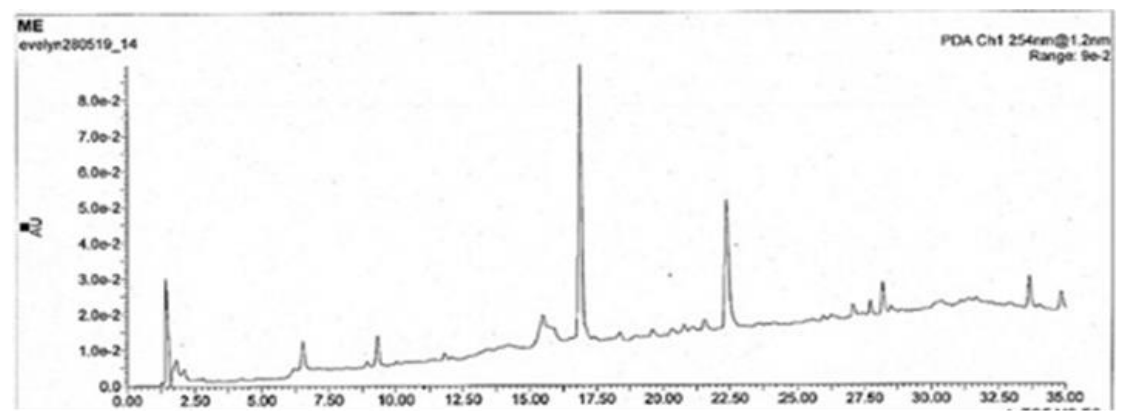


(b)

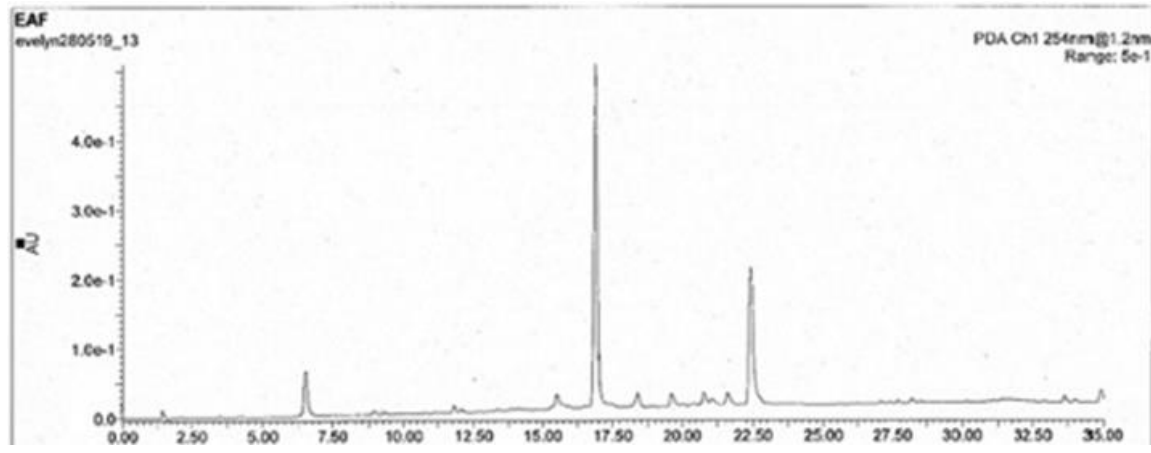

(c)

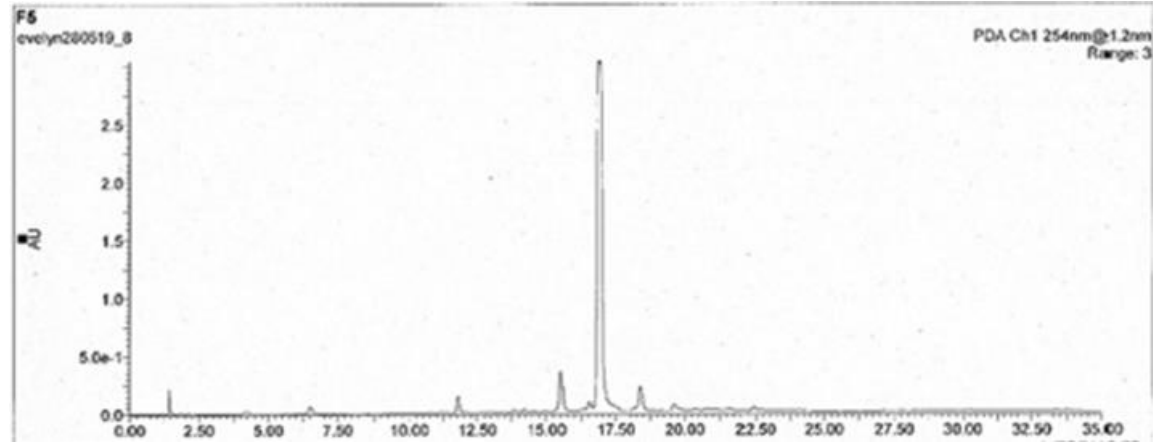

(d)<smiles>O=c1c(O[C@@H]2O[C@H](CO)[C@@H](O)[C@H](O)[C@H]2O)c(-c2ccc(O)cc2)oc2cc(O)cc(O)c12</smiles>

Figure 5 HPLC profile of Stenochlaena palustris leaves': (a) methanolic extract; (b) ethyl acetate fraction from the methanolic extract; and (c) fraction f5. (d) Chemical structure of kaempferol 3-0$\beta$-glucopyranoside

\section{Conclusions}

This study revealed several important findings on the standardization and optimization of $S$. palustris extraction, specifically regarding post-harvest treatment and extraction conditions. Attempts to preserve moisture and delay the wilting of fresh $S$. palustris leaves was shown to also protect their AGI activity. The smaller particle size of dried S. palustris powder was shown to better facilitate extraction of the principal AGI component at a 1:20 (w/v) extraction ratio. This study also identified astragalin as the active compound responsible for the AGI activity in $S$. palustris. This study's findings are expected to contribute to the further study and utilization of $S$. palustris as a functional ingredient for diabetes management based on its AGI activity.

\section{Acknowledgements}

This research project was supported by a grant from the Directorate General of Resources for Science, Technology and Higher Education of the Republic of Indonesia (contract number 0789/K4/KM/2018) and the Japan Student Services Organization (JASSO) Student Exchange Support Program (Scholarship for Short-Term Study in Japan) for the short-stay program at the School of Agriculture, Hokkaido University. The authors also express their gratitude to the students of the Agricultural Faculty at Palangkaraya 
University for their tremendous help in the sample collection, Dr. Hery Sutanto for his help with the chemical structure elucidation of the isolated compound, and Ms. Florence Ignatia, S.T., B. Eng for her help with the manuscript's proofreading.

\section{References}

Abarca-Vargas, R., Peña Malacara, C., Petricevich, V., 2016. Characterization of Chemical Compounds with Antioxidant and Cytotoxic Activities in Bougainvillea $x$ buttiana Holttum and Standl, (var. Rose) Extracts. Antioxidants (Basel), Volume 5(4), pp. 1-11

Arullappan, S., Sawai, S., Chee, L.A., Mahandan, M., Shanmugavelan, R., 2017. Phytochemical Screening and Evaluation of Cytotoxic Effect and Antioxidant Activity of Fractions Isolated from Stenochlaena palustris (Burm.f.) bedd. Leaves. Indian Journal of Pharmaceutical Education and Research, Volume 51(4), pp. S735-S740

Çam, M., İçyer, N., 2013. Phenolics of Pomegranate Peels: Extraction Optimization by Central Composite Design and Alpha-Glucosidase Inhibition Potentials. Journal of Food Scence and Technology, Volume 52(3), pp. 1489-1497

Chai, T.-T., Kwek, M.-T., Ong, H.-C., Wong, F.-C., 2015. Water Fraction of Edible Medicinal Fern Stenochlaena palustris Is a Potent $\alpha$-glucosidase Inhibitor with Concurrent Antioxidant Activity. Food Chemistry, Volume 186, pp. 26-31

Chai, T.-T., Panirchellvum, E., Ong, H.-C., Wong, F.-C., 2012. Phenolic Contents and Antioxidant Properties of Stenochlaena palustris, an Edible Medicinal Fern. Botanical Studies, Volume 53(4), pp. 439-446

Chear, N.J.Y., Khaw, K.Y., Murugaiyah, V., Lai, C.S., 2016. Cholinesterase Inhibitory Activity and Chemical Constituents of Stenochlaena palustris Fronds at Two Different Stages of Maturity. Journal of Food and Drug Analysis, Volume 24(2), pp. 358-366

Chebil, L., Humeau, C., Anthoni, J., Dehez, F., Engasser, J.-M., Ghoul, M., 2007. Solubility of Flavonoids in Organic Solvents. Journal Chemical \& Engineering Data, Volume 52(5), pp. $1552-1556$

Chen, X.M., Ma, Z., Kitts, D.D., 2018. Effects of Processing Method and Age of Leaves on Phytochemical Profiles and Bioactivity of Coffee Leaves. Food Chemistry, Volume 249, pp. 143-153

Choung, W.J., Hwang, S.H., Ko, D.S., Kim, S.B., Kim, S.H., Jeon, S.H., Choi, H.D., Lim, S.S., Shim, J.H., 2017. Enzymatic Synthesis of a Novel Kaempferol-3-O- $\beta$-D-Glucopyranosyl$(1 \rightarrow 4)-0-\alpha-D-$ Glucopyranoside using Cyclodextrin Glucanotransferase and Its Inhibitory Effects on Aldose Reductase, Inflammation, and Oxidative Stress. Journal of Agricultural and Food Chemistry, Volume 65(13), pp. 2760-2767

Dewi, D.S., Irfoni, A.R., Rahman, A., 2017. Kansei Engineering Approach for Designing a SelfMonitoring Blood Glucose Application. International Journal of Technology, Volume 8(2), pp. 272-282

Dianursanti, Siregar, A., Maeda, Y., Yoshino, T., Tanaka, T., 2020. The Effects of Solvents and Solid-to-Solvent Ratios on Ultrasound-Assisted Extraction of Carotenoids from Chlorella vulgaris. International Journal of Technology, Volume 11(5), pp. 941-950

Gangula, S.R., Govada, H., Matta, M., 2013. Phytochemical Screening and Inhibitory Effect of n-Butanol, Isopropanol and Water Extracts Leaf Extracts of Sapindus saponaria Vahl on Selected Pathogens. Advance in Applied Science Research, Volume 4(1), pp. 463-467

Gunawan-Puteri, M.D., Kawabata, J., 2010. Novel $\alpha$-glucosidase Inhibitors from Macaranga tanarius Leaves. Food Chemistry, Volume 123(2), pp. 384-389

Gunawan-Puteri, M.D.P.T., Josopandojo, B.M., Adiyoga, G.H., Kartawiria, I.S., Widiputri, D.I., 2016. Aqueous Extraction Optimization of C. Citratus for Development of Food Ingredients with Alpha Glucosidase Inhibitory Activities. In: Proceedings of the $2^{\text {nd }}$ 
International Conference on Science, Technology, and Interdisciplinary Research 2016, Lampung, Indonesia, pp. 55-61

Leng, V.K.W., 2016. Isolation and Structure Elucidation of Potent $\alpha$-glucosidase Inhibitory Bioactive Compound from Stenochlaena palustris by SPE, HPLC and NMR. Bachelor's Thesis, Faculty of Science, Universiti Tunku Abdul Rahman, Selangor, Malaysia

Mustarichie, R., Runadi, D., Ramdhani, D., 2017. The Antioxidant Activity and Phytochemical Screening of Ethanol Extract, Fractions of Water, Ethyl Acetate and n-Hexane from Mistletoe Tea (Scurrula atropurpurea BL. Dans). Asian Journal of Pharmaceutical and Clinical Research, Volume 10(2), pp. 1-5

Namvar, K., Mohammadi, A., Ataei Salehi, E., Feyzi, P., 2017. Evaluation of Solvent Effect (Methanol: Water Mixture) on the Phenolic Content and Antioxidant Activities of Stachys turcomanica Trautv. Journal of Pharmaceutical Science, Volume 23(3), pp. 244248

Neamsuvan, O., Sengnon, N., Seemaphrik, N., Chouychoo, M., Rungrat, R. Bunrasri, S., 2015. A Survey of Medicinal Plants around Upper Songkhla Lake, Thailand. African Journal of Traditional, Complementary, and Alternative Medicine, Volume 12(2), pp. 133-143

Nicholas, D., Chua, H.P., Saniah, K., 2013. Postharvest Treatment and Packaging System for Sarawak's Indigenous Midin Fern (Stenochlaena palustris). In: Proceedings of the Second International Symposium on Underutilized Plant Species: Crops for the FutureBeyond Food Security. Vol 2. International Society for Horticultural Science (ISHS). Kuala Lumpur, Malaysia. pp. 131-137

Nurmilatina, N., 2017. Analisis Komposisi Kimia Daun Kelakai (Stenochlaena Palustris Bedd.) dengan Berbagai Pelarut Menggunakan GCMS. (Chemical Composition Analysis of Stenochlaena palustris Bedd. Leaves using Various Solvents on GCMS). Jurnal Riset Industri Hasil Hutan, Volume 9(1), pp. 9-16

Ponnusamy, Y., Chear, N.J.Y., Ramanathan, S., Murugaiyah, V., Lai, C.S., 2013. Antioxidant and Antibacterial Properties of Malaysian Ferns Used Traditionally against Infection. J. Nat. Prod. Plant Resource, Volume 3(6), pp. 14-18

Quan, M., Liang, J., 2017. The Influences of Four Types of Soil on the Growth, Physiological and Biochemical Characteristics of Lycoris aurea (L' Her.) Herb. Scientific Reports, Volume 7(43284), pp. 1-9

Rahmawati, D., Rifky, N.A., Marpaung, A.M., 2017. Extraction and Stability Analysis of Antioxidant Activity from Stenochlaena palustris. In: Proceedings of the $4^{\text {th }}$ International Postgraduate Symposium on Food, Agriculture and Biotechnology, Mahasarakham University. Mahasarakham, Thailand, pp. 45-52

Saragih, B., Prakoso, H.T., Rahmadi, A., Emmawati, A., Kurniadinata, O.F., 2017. Phytochemicals, Quality and Glycemic Response Fern Red Herbal (Stenochlaena palustris). In: Proceedings of the $5^{\text {th }}$ Asian Academic Society International Conference Proceeding Series. Indonesian Student Association in Thailand (PERMITHA). Khong Kaen, Thailand, pp. 391-397

Tan, C., Wang, Q., Luo, C., Chen, S., Li, Q., Li, P., 2013. Yeast $\alpha$-glucosidase Inhibitory Phenolic Compounds Isolated from Gynura medica Leaf. International Journal of Molecular Science, Volume 14(2), pp. 2551-2558

Widiputri, D.I., Julisantika, I., Kartawiria, I.S., Gunawan-Puteri, M.D.P.T., Ignatia, F., 2020. Upscaling the Cymbopogon citratus (Lemongrass) Extraction Process to Obtain Optimum Alpha-glucosidase Inhibitor (AGI) Levels. International Journal of Technology, Volume 11(3), pp. 532-543

Wijaya, E., Widiputri, D.I., Rahmawati, D., 2017. Optimizing the Antioxidant Activity of Kelakai (Stenochlaena palustris) through Multiple Stage Extraction Process. In: 
Proceedings of the $3^{\text {rd }}$ International Symposium on Applied Chemistry 2017. American Institute of Physics (AIP) and Indonesian Institute of Sciences (LIPI). Jakarta, Indonesia. Volume 1904(Issue 1), p. 020034

Yang, L., Wen, K.S., Ruan, X., Zhao, Y.X., Wei, F., Wang, Q., 2018. Response of Plant Secondary Metabolites to Environmental Factors. Molecules, Volume 23(4), pp. 762-770 